\title{
POPULATION GENETICS, SPECIES BOUNDARIES, AND CONSERVATION IN THE MAGNOLIA PACIFICA SPECIES COMPLEX ALONG A CONTINENTALITY AND MOISTURE GRADIENT IN WESTERN MEXICO
}

\section{GENÉTICA DE POBLACIONES, DELIMITACIÓN DE ESPECIES Y CONSERVACIÓN EN EL COMPLEJO DE ESPECIES MAGNOLIA PACIFICA A LO LARGO DE UN GRADIENTE DE CONTINENTALIDAD Y HUMEDAD EN EL OCCIDENTE DE MÉXICO}

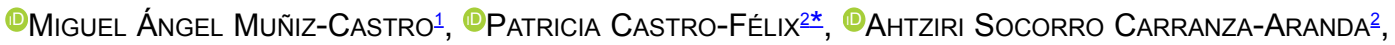

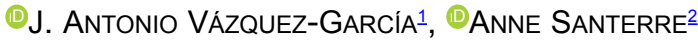

\begin{abstract}
'Laboratorio de Ecosistemática, Instituto de Botánica, Departamento de Botánica y Zoología, Centro Universitario de Ciencias Biológicas y Agropecuarias, Universidad de Guadalajara, México.

'Laboratorio de Marcadores Moleculares en Biomedicina y Ecología, Instituto de Investigación Biomédica y Genética Molecular, Departamento de Biología Celular y Molecular, Centro Universitario de Ciencias Biológicas y Agropecuarias, Universidad de Guadalajara, México.
\end{abstract}

*Corresponding author: luz.castro@academicos.udg.mx

\begin{abstract}
Background: In western Mexico, the Magnolia pacifica complex includes three morphologically defined, endemic, and endangered species, distributed along a $215 \mathrm{~km}$ continentality and moisture gradient: Magnolia pugana, M. pacifica s.s., and M. vallartensis.

Hypothesis: Genetic evidence supports the taxonomical classification of the M. pacifica complex.

Study site and dates: Western Mexico, samples were collected in 2012-2015.

Methods: Six Inter-Simple Sequence Repeats (ISSR) primers amplified 76 clear and reproducible fragments in 278 individuals from 10 representative localities of the $M$. pacifica complex. ISSR dataset was analyzed using STRUCTURE 2.3.4, UPGMA clustering, Barrier 2.2, and AMOVA. Genetic diversity parameters were also estimated.

Results: Genetic analyses revealed two main groups: M. pugana and M. pacifica s.s.-M. vallartensis. Two subpopulations within each group were evidenced, particularly M. pacifica s.s. was separated from M. vallartensis. Geographical barriers to gene flow were identified. AMOVA revealed a similar and significant proportion of variation between and within groups. M. pugana has lower genetic diversity and higher differentiation than the M. pacifica s.s-M. vallartensis group.

Conclusions: Our results support the recognition of M. pugana as a genetically distinct lineage from M. pacifica s.s and M. vallartensis, but did not reveal a clear species boundary between the last two taxa. Geographical barriers and distance isolation might explain the genetic structure and differentiation pattern within the M. pacifica s.s. species complex. All main groups and subgroups defined in this study should be considered as separate conservation units, and concerted efforts are needed to protect them.
\end{abstract}

Keywords: ISSRs, Magnoliaceae, plant conservation.

\section{Resumen}

Antecedentes: En el occidente de México, el complejo Magnolia pacifica incluye tres especies definidas morfológicamente, endémicas y en peligro de extinción, distribuidas en un gradiente de continentalidad y humedad de $215 \mathrm{~km}$ : Magnolia pugana, M. pacifica s.s. y M. vallartensis.

Hipótesis: La evidencia genética respalda la clasificación taxonómica del complejo M. pacifica.

Área y años de estudio: Occidente, México, muestras colectadas en 2012-2015.

Métodos: Seis iniciadores de Inter Secuencias Simples Repetidas (ISSR) amplificaron 76 fragmentos claros y reproducibles en 278 individuos de 10 localidades del complejo M. pacifica. Los datos se analizaron utilizando STRUCTURE 2.3.4, agrupamiento UPGMA, Barrier 2.2, y AMOVA. Además se evaluó la diversidad genética.

Resultados: Los análisis revelaron dos grupos principales: M. pugana y M. pacifica s.s.-M. vallartensis. Dos subpoblaciones dentro de cada grupo fueron evidentes, particularmente $M$. pacifica s.s. y $M$. vallartensis fueron separadas. Se identificaron barreras geográficas al flujo genético. AMOVA reveló una proporción de variación similar y significativa entre y dentro de los grupos. M. pugana presenta menor diversidad genética y mayor diferenciación que M. pacifica s.s. y M. vallartensis.

Conclusiones: Nuestros resultados apoyan el reconocimiento de M. pugana como una línea genéticamente distinta de M. pacifica s.s. y M. vallartensis, no revelaron una clara delimitación de especies entre estos dos últimos taxa. Barreras geográficas y aislamiento por distancia explicarían la estructura y el patrón de diferenciación del complejo M. pacifica. Los grupos principales y subgrupos definidos en este estudio deben considerarse unidades de conservación separadas, es necesario concertar esfuerzos para protegerlos.

Palabras clave: Conservación de plantas, ISSRs, Magnoliaceae. 
Magnoliaceae Juss. is an old family in the evolutionary history of flowering plants and displays an important Holarctic fossil record of over 100 million years (APG IV 2016, Romanov \& Dilcher 2013), estimated to have originated between 113.15 - 104.71 Mya (Magallón et al. 2015). It includes ca. 350 species of trees and shrubs within two subfamilies: Liriodendroideae (containing only Liriodendron L. with two species) and Magnolioideae (comprising only Magnolia L.) (Figlar \& Nooteboom 2004, Figlar 2006, Kim \& Suh 2013, Vázquez-García et al. 2016). Magnolias are currently found in temperate and tropical areas of Asia and the Americas (APG IV 2016). About half of the species occur in the New World, from temperate eastern North America through Mexico, Central America, the Caribbean islands and northern South America to Bolivia and Brazil (Lozano-Contreras 1994, VázquezGarcía 1994, Frodin \& Govaerts 1996, Vázquez-García et al. 2016). Mexico and Colombia, with nearly three dozens of species each, are the two magnolia richest countries in the continent (Lozano-Contreras 1994, Vázquez-García 1994, Vázquez-García et al. 2017). Their showy and fragrant flowers make magnolias of great horticultural and ethnobotanical value throughout the world.

The Magnolia pacifica species complex, subg. Magnolia, sect. Magnolia (Figlar \& Nooteboom 2004) consists of four morphologically close and currently recognized endemic species of Mexico (Vázquez-García 1994, Vázquez-García et al. 2002, 2012, 2013): Magnolia tarahumara (A.Vázquez) A.Vázquez, Magnolia pacifica A.Vázquez, Magnolia pugana (Iltis \& A.Vázquez) A.Vázquez \& Carvajal, and Magnolia vallartensis A.Vázquez \& MuñizCastro. M. tarahumara inhabits northwestern Mexico (Vázquez-García et al. 2013) whereas M. pacifica, M. pugana, and M. vallartensis belong to the "Pacific southwest" group sensu Vázquez-García (1994). Magnolia species in the Pacific southwest region are distributed along a continentality and moisture gradient because of their different distances to the Pacific Ocean, and only survive in permanent humid microclimates such as very moist ravines (on the coastal mountains), or adjacent to springs and permanent streams (in the interior seasonally-dry valleys and ravines). The lands of the interior of the continents have a different climate than the lands near the coasts because they do not receive (or receive in a smaller proportion) the moderating effect of the humidity coming from the sea. The interior, unlike the coasts, presents a drier and a more variable and extreme climate, with a greater range of variation of diurnal and annual temperatures (Snow 2005).

Most reports within the $M$. pacifica complex are limited to the description of species based on qualitative morphological and geographical information as well as ecological differences. In particular, $M$. pugana was first treated as a subspecies of $M$. pacifica (Vázquez-García
1994); afterward, it was described as a species because of its distinctive characters such as the numbers of carpels per fruit and stamens per flower, glabrous peduncles, and tepals shape, which allowed to clearly separate it from $M$. pacifica (Vázquez-García et al. 2002). Afterward, M. vallartensis was also described as a new species based on the form and size of its leaves, number of carpels per fruit, number and shape of tepals, and height of the trees (Vázquez-García et al. 2012). Since phenotypic plasticity is one of the major traits by which plants can cope with the variability of environmental factors (Gratani 2014), morphological differences between species of the $M$. pacifica complex might be the result of ecological differences. Thus, in order to get a more reliable species delimitation within this complex, morphological boundaries must be validated with molecular data (Schlick-Steiner et al. 2010).

Population genetic analyses are considered complementary and useful tools for species delimitation in complex groups (Sites \& Marshall 2004). The population approach for species delimitation is based on the unified, general species concept proposed by de Queiroz (2005, 2007). This concept describes species as population-level evolutionary lineages. Under this notion, species generally show a higher genetic divergence from one another than populations within species (Drummond \& Hamilton 2007). Nevertheless, the levels of differentiation among species depend on the time of separation and amount of gene exchange (Hey \& Pinho 2012). In trees, factors such as long generation time, large effective population sizes (Rosenberg 2003), and frequent introgression, increase the opportunity of sharing polymorphisms (Zhou et al. 2017), which makes the definition of species even more problematic. Thus, delimitation of recently diverged tree species based on DNA markers is particularly challenging, and sequence data (nDNA, mtDNA, cpDNA) used in traditional phylogenetic analysis may not be informative enough. In particular, mitochondrial DNA is generally insufficiently polymorphic in plants, and incongruences between phylogenies obtained from nDNA and cpDNA seem to be frequent (Wang et al. $\underline{2014)}$.

The population genetic approach is widely used for species identification and evolutionary analysis of closely related plant species (Medrano et al. 2014, Stiehl-Alves et al. 2017, Esfandani-Bozchaloyi et al. 2018, Sheidai et al. 2018, Pinangé et al. 2019). For this purpose, it is recommended to use highly polymorphic markers with large genome coverage (Duminil \& Di Michele 2009) which are not influenced by environment nor affected by natural selection (Holderegger et al. 2006), but experience high rate of intraspecific gene flow (Petit \& Excoffier 2009). Dominant markers and microsatellites (a codominant marker) have demonstrated to be useful for species delimitation, however, dominant markers have a higher 
genome coverage compared with microsatellites, and have been efficient to provide information on species boundaries (Hausdorf \& Hennig 2010). Inter simple sequence repeats (ISSR) are dominant and neutral multi-locus markers amplified by polymerase chain reaction (PCR) in the presence of single primers complementary to simple sequence repeats (SSR) or microsatellites (Zietkiewicz et al. 1994, Reddy et al. 2002). The high evolutionary rate, nuclear origin and a large number of loci scored, make ISSR markers useful to define inter-specific boundaries between closely related plant species (Fernandes-Lima et al. 2015, Rodrigues et al. 2015, Stiehl-Alves et al. 2017). The use of Bayesian model-based clustering methods for the analysis of multi-locus markers has proven to be a useful and recommended approach to identify species boundaries (Petit \& Excoffier 2009, Hausdorf \& Hennig 2010). These tools can be particularly powerful when combined with other methods, such as phylogenetic analyses (Noble et al. 2010).

Due to the large number of threatened Magnolia species worldwide, the evaluation of its genetic diversity to propose and implement conservation measures has become a major international task (Cires et al. 2013). Out of the 306 Magnolia species registered in the IUCN 2019 Red List of Magnoliaceae, 121 are listed as critically endangered or endangered; in particular, the Neotropical region holds the highest proportion $(75 \%)$ of threatened magnolias (Rivers et al. 2016). Based on its restricted geographical distribution $\left(4,732 \mathrm{~km}^{2}\right)$ and a continued decline in the extent of occurrence and quality of its habitat, $M$. pacifica has been classified as endangered according to Cicuzza et $\underline{\text { al. (2007) }}$ and Rivers et al. (2016). M. pugana has also been categorized as endangered because of its small extent of occurrence $\left(2,460 \mathrm{~km}^{2}\right)$ and habitat degradation (Rivers et al. 2016). M. vallartensis has been considered as critically endangered as its extent of occurrence was estimated to be less than $100 \mathrm{~km}^{2}$ (Rivers et al. 2016). The conservation of genetic diversity is critical for the long-term survival of a species (Schemske et al. 1994), however, information about the levels and distribution of genetic variation of these three taxa is not available. Here we evaluate the genetic structure, differentiation and diversity of the $M$. pacifica species complex using ISSR markers in order to 1) analyze species boundaries and 2) contribute to the conservation status assessment of each taxon.

\section{Materials and methods}

Study species and distribution. The studied taxa of the Pacific southwest $M$. pacifica complex exhibit differences in morphology, phenology, and habitat along a continentality and moisture gradient (Table 1) (Figures 1 3). Plant voucher specimens were collected in 10 localities for reference and morphological revision, and were deposited at the IBUG Herbarium of the Universidad de Guadalajara (Supplementary data 1).

M. pugana is endemic to the center of the state of Jalisco and southern Zacatecas, in the confluence of the TransMexican Volcanic Belt (TMVB) and the southern end of the Sierra Madre Occidental (SMO) physiographic provinces (INEGI 2001) (Figure 3). This taxon, being nearly 170 $215 \mathrm{~km}$ away from the sea, thrives in a seasonally-dry continental climate (AAR ca. $833-980 \mathrm{~mm}$ ), in gallery riparian forests, on the side of permanent streams and springs; surrounded by tropical seasonal dry forests and pine-oak forests, usually exposed to high water stress (Vázquez-García et al. 2002).

M. pacifica s.s. is distributed in montane cloud forests of western Jalisco and Nayarit, in the confluence of three mountain physiographic provinces, the TMVB, SMO and Sierra Madre del Sur (SMS). Because of its proximity to the Pacific Ocean (40-70 km from the sea) it is exposed to higher levels of precipitation (AAR ca. 1,100 - 1,364 mm), both vertical (rain) and horizontal (clouds, mist, and fog) (Vázquez-García 1994).

$M$. vallartensis is found only in the west of Jalisco state, in the municipalities of Puerto Vallarta and Cabo Corrientes, in the northwestern limit of SMS; this species inhabits montane cloud forests and its ecotone with tropical subevergreen forests, close to the Pacific Ocean (0.5-20 km from the sea) and receives moisture throughout the year (AAR ca. 1,348-1,591 mm) (Vázquez-García et al. 2012).

Plant material and DNA extraction. This study includes 278 samples from 10 localities: four belong to M. pugana, three to $M$. pacifica s.s., and three to $M$. vallartensis (Figure 3). These selected locations cover the geographical distribution range of each taxon. Ten field trips were conducted from February 2012 to August 2015. In each locality 21 to 33 georeferenced (GPS Garmin, $60 \mathrm{CS}$ ) adult magnolia trees were randomly sampled; individuals were separated by a minimum distance of $100 \mathrm{~m}$ to reduce the probability of sampling from family clusters. From each tree, fresh mature leaves were collected, stored in plastic bags filled with silica gel and taken to the laboratory. Genomic DNA was extracted using the CTAB method reported by Cota-Sánchez et al. (2006) with slight modifications. The DNA concentration was quantified at $\mathrm{A}_{260}$ with a Spectro UV-VIS RS digital spectrophotometer (LaboMed Inc., Los Angeles, CA, USA).

$I S S R-P C R$. In an initial step, twenty-three anchored and one un-anchored ISSR primers were screened using DNA extracted from five randomly selected samples. Out of the screened primers, six were selected based on their amplification pattern. In order to test for reproducibility of 
the PCR with the selected primers, duplicate amplifications were performed with fifteen DNA samples chosen at random. Amplifications were carried out in $20 \mu \mathrm{L}$ reaction volumes containing $75 \mathrm{ng}$ of genomic DNA, 1X PCR buffer, $2.5 \mathrm{mM} \mathrm{MgCl}, 0.2 \mathrm{mM}$ of each dNTP (Invitrogen), $1 \mu \mathrm{M}$ of the primer, and $0.8 \mathrm{U}$ Taq polymerase (Invitrogen) in a PTC-100 thermal cycler (MJ Research, Inc.) programmed for an initial denaturing step of $3 \mathrm{~min}$ at $95^{\circ} \mathrm{C}$ and 40 cycles of the following temperature profile: $45 \mathrm{~s}$ at $95{ }^{\circ} \mathrm{C} ; 45 \mathrm{~s}$ at $50{ }^{\circ} \mathrm{C}$ (primers 810,814 and 857 ) or $56{ }^{\circ} \mathrm{C}$ (primer 834) and $60{ }^{\circ} \mathrm{C}$ (primers 836 and 855); and 2 min at $72{ }^{\circ} \mathrm{C}$. Cycling was concluded with a final extension at $72{ }^{\circ} \mathrm{C}$ for $10 \mathrm{~min}$. Amplification products were separated by electrophoresis on $2 \%$ agarose gels (standard and low melting point agarose at 2:1 ratio) with $1 \mathrm{X}$ TBE buffer, under $100 \mathrm{~V}$ for approximately $2 \mathrm{~h}$. The gels were stained with ethidium bromide $(1 \mu \mathrm{g} / \mathrm{mL})$ and photographed under UV light with a Kodak photo documentation system (Kodak ID Image Analysis Software, version 3.5). Lengths of the DNA fragments were estimated using a 100 bp DNA ladder (Invitrogen).

Data analysis. The presence or absence of consistently reproducible DNA bands in the stained gels was scored manually. All smeared and weak bands were excluded. A binary data matrix was constructed for each sampling site, with fragments of the same size considered as the same locus. The species boundaries in the M. pacifica complex were examined through a multi-analytic strategy. First, Bayesian clustering analyses were performed with the software STRUCTURE 2.3.4 to infer the probability to assign the genotype data set to a given number of clusters (K) (Pritchard et al. 2000). Admixture proportions (Q) of all localities and individuals were estimated. Fifteen independent runs were conducted for $\mathrm{K}$ values between one (panmixia) and 11, using 150,000 MCMC (Markov Chain Monte Carlo) iterations and a burn-in period of 20,000, admitting the admixture model of ancestry and correlated allele frequencies. This analysis was performed in a hierarchical framework to identify the complete substructure in the data set. In a first run, STRUCTURE was executed with the full dataset, and then independent runs were executed for each genetic group revealed by this analysis. The results of all STRUCTURE analyses were clustered and averaged using CLUMPACK (Cluster Markov Packager Across K) (Kopelman et al. 2015). Evannos's index (Evanno et al. 2005) was used to detect the best $\mathrm{K}$ in the dataset. Second, a dendrogram based on Nei's genetic distance (Nei 1972) was constructed by using TFPGA 1.3 (Miller 1997), implementing an unweighted pair group method of cluster analysis that uses arithmetic averages (UPGMA). A bootstrap analysis using 1,000 replicates was performed to assess support for the inferred groups. Third, in order to identify genetic barriers, Barrier 2.2 software (Manni et al. 2004) was used to correlate geographical and genetic distances between populations using Monmonier's maximum difference algorithm (Monmonier 1973), with significance tested by means of 1,000 bootstrap matrices of genetic distance. Geographical coordinates of populations were used to obtain a Voronoï tessellation where barriers were delineated. Finally, analyses of molecular variance (AMOVA) were performed using GenAlEx 6.5. The distribution of the genetic variance was assessed in 1) morphology-based taxonomic groups and, 2) Bayesian analysis-based groups. AMOVAs were also run for each putative studied species.

Table 1. Morphological characteristics of Magnolia species investigated in this study.

\begin{tabular}{lccc}
\hline Traits & M. pugana & M. pacifica s.s. & M. vallartensis \\
\hline Mature tree height (m) & $10-25(30)$ & $15-28(35)$ & $8-15(23)$ \\
Mature tree dbh (cm) & $30-80(160)$ & $40-80(160)$ & $20-35(47)$ \\
Leaf shape & Narrowly elliptical to elliptical, to & Narrowly elliptical to elliptical, to & Elliptic to wide elliptic or oblong \\
lanceolate & obovate & Frequently obtuse \\
Leaf apex & Frequently acute & Frequently acute & $13.5-27.8 \times 6-14.8$ \\
Leaf size (cm) & $12-22 \times 2.5-8$ & $8-17(18) \times(3) 5-6(8)$ & Internodes glabrous, nodes \\
Peduncle & Essentially glabrous to pubescent at & Pubescent throughout or at least at the & pubescent \\
Sepals shape & the base & nodes & Oblong \\
Petals (number) & Widely obovate & Oblong & $6-8$ \\
Stamens (number) & $6-7$ & 6 & $75-82(118)$ \\
Carpels & $92-100$ & $100-110$ & $10-19$ \\
Fruit (polyfollicle) shape & $25-35$ & $(18)$ 23-28 (37) & Narrowly oblongoid \\
Locule shape & Oblongoid & Elliptic, much longer than wide & Elliptic, much longer than wide \\
\hline
\end{tabular}




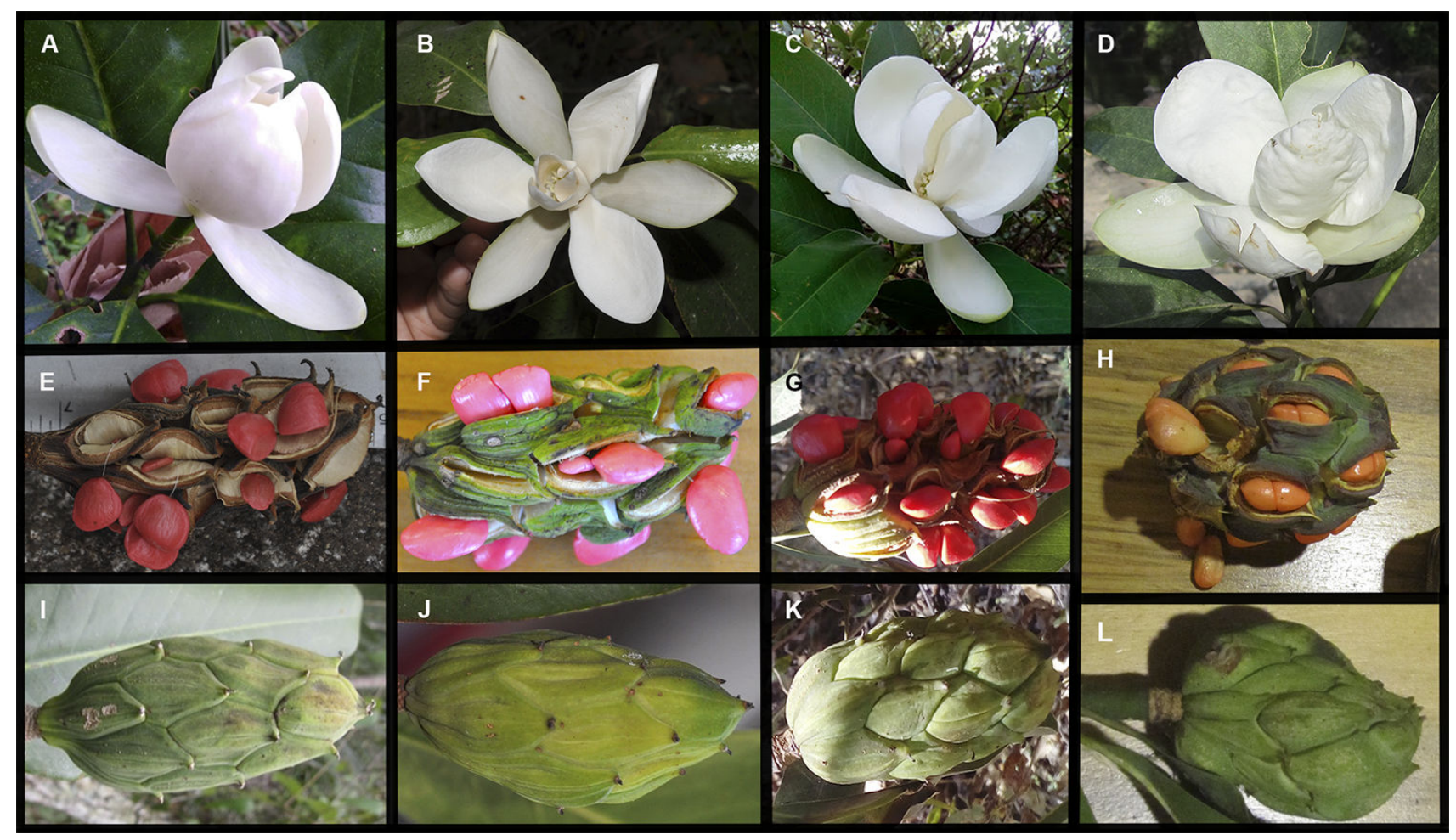

Figure 1. Distinctive morphological characters of Magnolia vallartensis (A, E, I), M. pacifica s.s. (B, F, J), M. pugana s.s. (C, G, K), and M. pugana Barrancae group (D, H, L). A-D. Flowers. E-H. Dehiscent mature fruits. I-L. Mature fruits before dehiscence. Photographs by J. Antonio Vázquez-García and Miguel Á. Muñiz-Castro.

To assess the genetic diversity of genetic groups, each taxon, and each locality, the percentage of polymorphic bands (P) (0.95 level) and Shannon's diversity index (I) were estimated with POPGENE v. 1.31 (Yeh et al. 1999). Nei's gene diversity $\left(\mathrm{H}_{\mathrm{E}}\right)$, intrapopulation genetic diversity $(\mathrm{Hs})$, and total genetic diversity $\left(\mathrm{H}_{\mathrm{T}}\right)$ were estimated using GenoDive Beta 2.0 (Meirmans \& Van Tienderen 2004). $\mathrm{G}_{\mathrm{ST}}$ (Nei 1972) and D (Jost 2008) differentiation indexes were also calculated. In order to test for differentiation between localities, Exact Tests (Raymond \& Rousset 1995) for locality pairs were performed with TFPGA 1.3 (Miller 1997), with 1,000 dememorization steps, followed by 20 batches of 2,000 permutations per batch; significance values were obtained following the Fisher's method that combines probabilities of exact tests (Sokal \& Rohlf 1995). Finally, pairwise genetic distances among localities were estimated to test for significant correlation with the corresponding geographical distances, a Mantel test was performed with TFPGA 1.3 (Miller 1997) using 999 random permutations. Because the three studied taxa belong to a complex of closely related species, this analysis was done for all localities grouped as one species complex and for each main genetic cluster.

Conservation status assessment. Extinction risk evaluation of the three studied taxa was performed using the IUCN Red List Criteria (criteria B1 + B2, IUCN 2019) and the GeoCAT software tool (Kew-IUCN-VIBRANT 2019). The records used for the delimitation of the Extent of Occurrence (minimum convex polygon, EOO) and the Area of Occupancy (grid cell area with occupancy, AOO) of each taxon were obtained from IBUG herbarium specimens, the GBIF, Tropicos.org, and REMIB-CONABIO databases. AOO calculation was based on the IUCN default cell width of $2 \mathrm{~km}$. Additionally, the criterion C-2 (Genetics) of the Method of Extinction Risk Evaluation of Plants in Mexico (MER) from the Mexican Official Norm 059 (SEMARNAT 2010) was used to contribute partially to the MER assessment. Criterion C-2 proposes that (1) if species has heterozygosity $(\mathrm{He})<10-20 \%$ (depending on the molecular marker used) and (2) a genetic differentiation (Gst or Fst) $>20 \%$, it has a higher threatened status or extinction risk. 
Taxa delimitation in the M. pacifica species complex

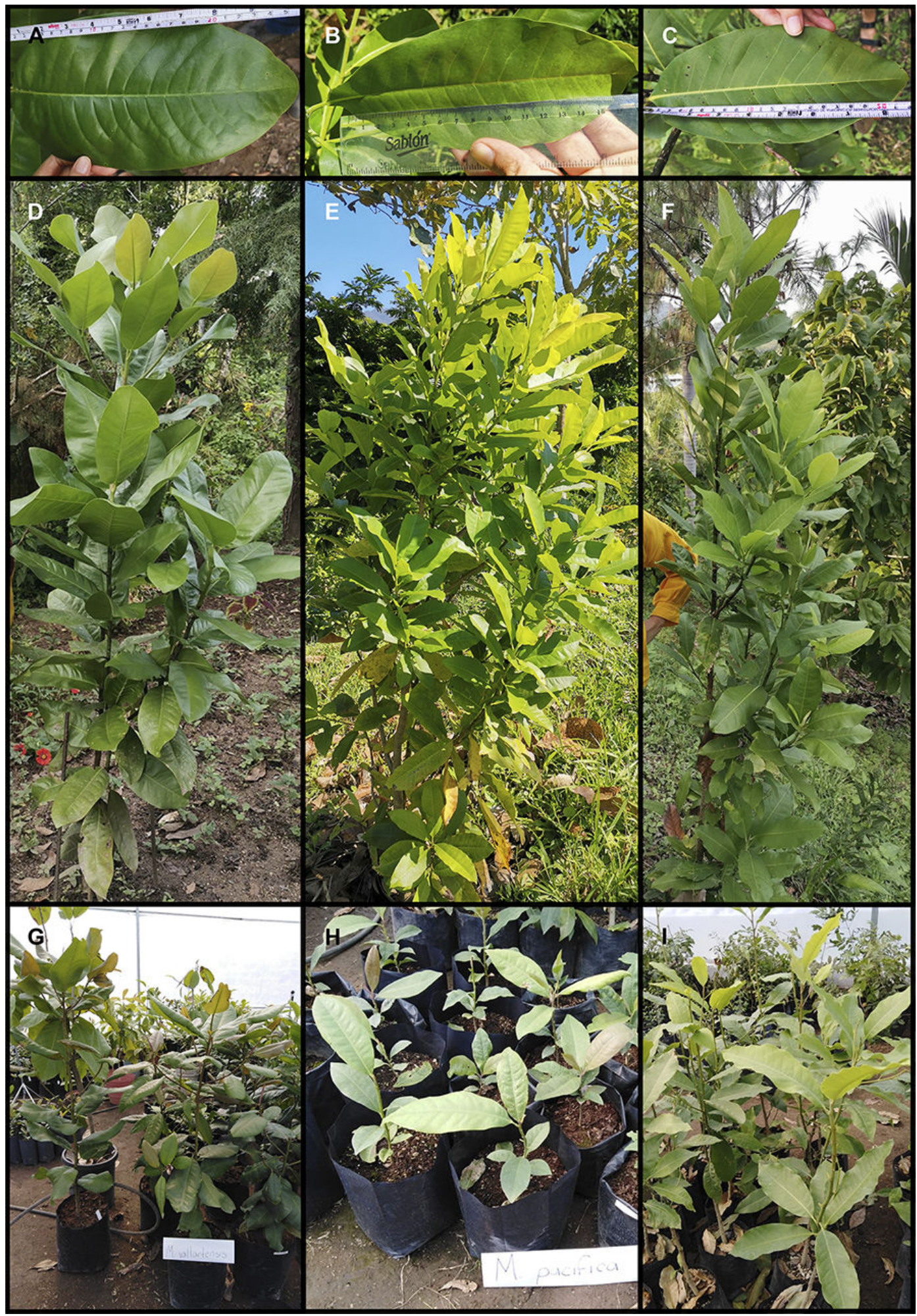

Figure 2. Distinctive morphological characters of Magnolia vallartensis (A, D, G), M. pacifica s.s. (B, E, H), and M. pugana s.s. (C, F, I), growing simultaneously in the same place. A-F. Leaves and young trees growing in the Vallarta Botanical Gardens (in the coast of Jalisco, at $360 \mathrm{~m}$ a.s.l). G-I. Young trees growing at the Instituto de Botánica from Universidad de Guadalajara (IBUG) (in the center of Jalisco, at 1,660 m a.s.l). Photographs A-F by Leonardo Campos, G-I by Alondra Salomé Ortega. 


\section{Results}

ISSR diversity. Primers 810, 814, 834, 836, 855 and 857 produced the best amplification patterns. Each primer amplified between eight and 16 DNA fragments, ranging in size from 300 to $1,650 \mathrm{bp}$ (Table 2). A total of 76 clear and reproducible amplified DNA fragments were analyzed, of which 41 were polymorphic among all samples tested, with each primer displaying from three to 10 polymorphic fragments. The $900 \mathrm{bp}$ (primer 834) and $850 \mathrm{bp}$ (primer 855) ISSR loci did not amplify $M$. pugana samples.

Species boundaries and genetic clustering. The Bayesian analysis with the full data set identified a value of $K=2$ as the most likely number of genetic clusters (Figure 4). Alpha values were monitored and convergence was reached following the 20,000 iterations in the burn-in period. The analysis revealed one genetic cluster for the four M. pugana localities and another cluster including the six localities of M. pacifica s.s. and M. vallartensis. Thus, the localities of $M$. pugana can be assigned to one population, and the localities of M. pacifica s.s. and M. vallartensis to a second population. The $M$. pugana cluster was highly homogeneous internally with almost no uncertain assignments at the localities ( $\geq 93 \%$ ) or individual level
( $>97 \%$ ); an individual membership coefficient threshold of $\mathrm{Q}>0.8$ was used to distinguish between pure individuals and individuals of admixed ancestry $(\mathrm{Q}<0.8)$. The $M$. pacifica s.s. $M$. vallartensis group was less homogeneous than the $M$. pugana group; the localities of BA and CSJ exhibited 78 and $75 \%$ of assignment at this cluster, respectively; the rest of the localities were exclusively made up of this genetic cluster ( $\geq 93 \%$ ); admixed individuals were also more common in this group, as only $88 \%$ of individuals were assigned to this cluster.

In order to reveal further genetic substructure within each of the two main clusters, a second Bayesian analysis was run, and a value of $\mathrm{K}=2$ was the most likely number of genetic subgroups within each cluster (Figure 4). The $M$. pugana main group was divided into the ALV-ASL and RV-APV subgroups, whereas the $M$. pacifica s.s.$M$. vallartensis group was subdivided into $M$. pacifica s.s. and $M$. vallartensis subgroups. The proportions of individuals assigned to each the M. pugana and the M. pacifica-M. vallartensis subgroups were 70 and $74 \%$, respectively. Similar to STRUCTURE results, two major clusters were identified in the UPGMA dendrogram (Figure 5), the first one included the four localities of $M$. pugana, and the second one the six localities of $M$. pacifica s.s. and M. vallartensis. The bootstrap analysis showed a

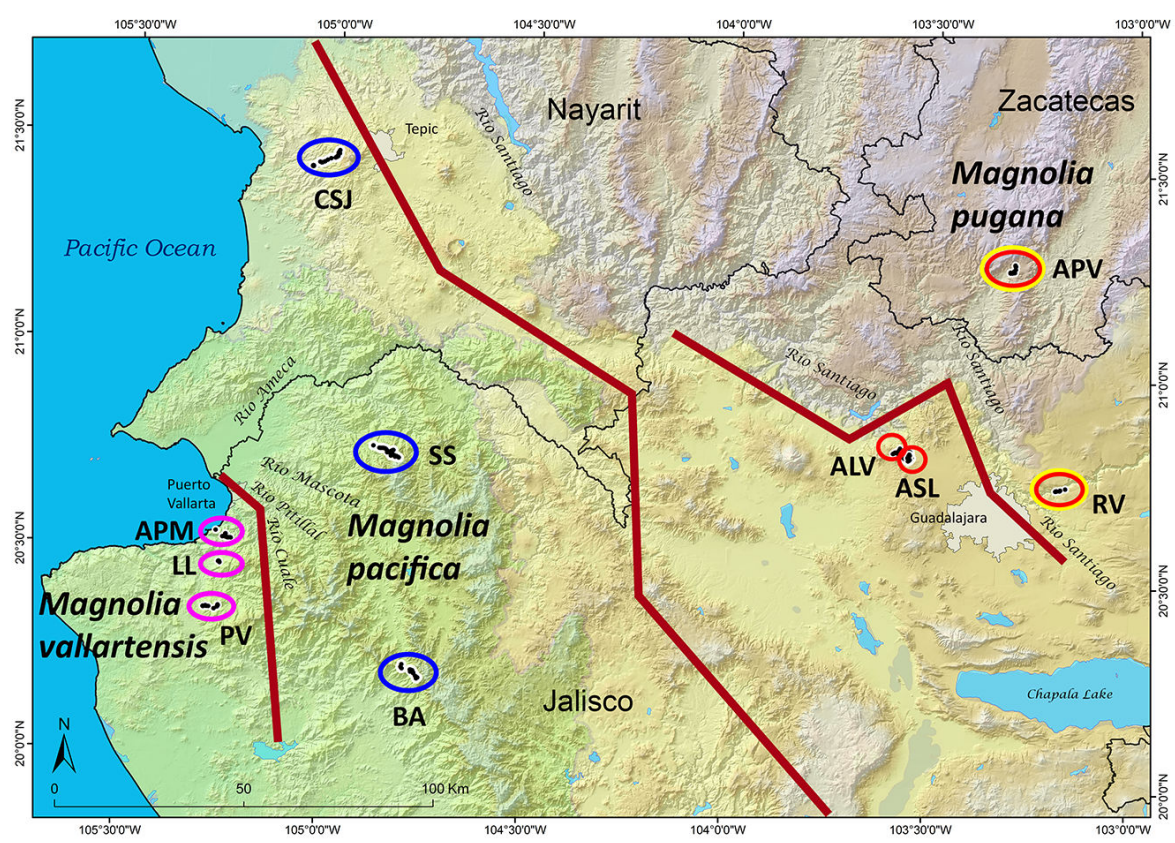

Figure 3. Study area in western Mexico. Localities are marked with ovals, pink for M. vallartensis, blue for M. pacifica and red for M. pugana (with yellow for the Barrancae group). The physiographic provinces are colored (semi-transparent) with turquoise (Pacific Coastal Plain), purple (Sierra Madre Occidental), green (Sierra Madre del Sur), and yellow (Trans-Mexican Volcanic Belt). Locality names are APM (Arroyo Palo María), LL (Las Lajitas), PV (Provincia), CSJ (Cerro San Juán), SS (San Sebastián), BA (Bosque de Arce), ALV (Arroyo La Virgen), ASL (Arroyo San Lorenzo), RV (Río Verde), APV (Arroyo Palo Verde). Dark red lines indicate the barriers to gene flow identified by Monmonier's algorithm. 
Taxa delimitation in the M. pacifica species complex

Table 2. Inter-simple sequence repeat (ISSR) primers used for the genetic analysis of the Magnolia pacifica species complex.

\begin{tabular}{|c|c|c|c|c|c|c|}
\hline \multirow{2}{*}{ Primer code } & \multirow{2}{*}{ Sequence $\left(5^{\prime}-3^{\prime}\right)$} & \multirow{2}{*}{ Annealing temperature $\left({ }^{\circ} \mathrm{C}\right)$} & \multicolumn{4}{|c|}{ Fragments } \\
\hline & & & Number & Polymorphic & Exclusive & Size (pb) \\
\hline UBC810 & $(\mathrm{GA})_{8} \mathrm{~T}$ & 50 & 16 & 5 & & $380-1350$ \\
\hline UBC814 & $(\mathrm{CT})_{8} \mathrm{~A}$ & 56 & 8 & 3 & & $630-1200$ \\
\hline UBC834 & $(\mathrm{AG})_{8} \mathrm{YT}$ & 56 & 13 & 10 & 1 & $410-1650$ \\
\hline UBC836 & $(\mathrm{AG})_{8} \mathrm{YA}$ & 60 & 14 & 9 & & $290-1150$ \\
\hline UBC855 & $(\mathrm{AC})_{8} \mathrm{YG}$ & 60 & 10 & 4 & 1 & $320-1600$ \\
\hline UBC857 & $(\mathrm{AC})_{8} \mathrm{CTC}$ & 50 & 15 & 10 & & $320-870$ \\
\hline Total & & & 76 & 41 & 2 & \\
\hline
\end{tabular}

value of $100 \%$ at this node, indicating strong support for these groups. Within the cluster of M. pugana, the localities ALV and ASL form one subgroup, and RV and APV form another one, however, the node had a very weak bootstrap support value $(<50 \%)$. Within the second main cluster, the localities of $M$. pacifica s.s. form one subgroup and the localities of $M$. vallartensis form a second one, with a bootstrap support value of $74 \%$.

Three geographical boundaries were detected, using Monmonier's algorithm (Figure 3). One barrier separates the two subpopulations of M. pugana. A second geographical barrier was revealed between M. pugana and the genetic group M. pacifica s.s.-M. vallartensis and finally another barrier separates M. pacifica s.s. from M. vallartesis. All geographical boundaries had $100 \%$ bootstrap support.

The AMOVA on the morphology-based taxonomic groups showed that $84 \%$ of the genetic variation was found within localities, and that only $8 \%$ was explained by differences among species, and a similar proportion was due to differences among localities within each taxon. Similar results were revealed by the AMOVA on the Bayesian genetic analysis-based groups (Table 3 ). All components of molecular variance were significant ( $p$ value 0.001 ).

Genetic diversity and differentiation. The percentage of polymorphic loci (P), Shannon's index (I) and heterozygosity $\left(\mathrm{H}_{\mathrm{T}}\right)$ were $\mathrm{P}=51 \%, \mathrm{I}=0.268, \mathrm{H}_{\mathrm{T}}=0.158 \pm$ 0.023 and $\mathrm{P}=53 \%, \mathrm{I}=0.283, \mathrm{H}_{\mathrm{T}}=0.174 \pm 0.024$ for the $M$. pugana and $M$. pacifica s.s. $M$. vallartensis genetic groups, respectively. The $\mathrm{P}$ value per taxon varied from $46 \%$ to $51 \%$, with an overall mean of $64 \%$ (Table 4 ). Shannon's index (I) ranged from 0.268 to 0.275 , with a total I of 0.309 . Heterozygosity $\left(\mathrm{H}_{\mathrm{T}}\right)$ per taxon ranged from 0.158 \pm 0.023 to 0.175 , with an overall mean of $0.178 \pm 0.023$. Genetic diversity within populations $\left(\mathrm{H}_{\mathrm{s}}\right)$ ranged from 0.134 (M. pugana) to 0.156 (M. pacifica s.s.-M. vallartensis) with an average of $0.153 \pm 0.022$. Genetic diversity also varied among localities; M. pugana localities had the lowest genetic diversity parameters, whereas BA locality of M. pacifica s.s. showed the highest genetic diversity.

Differentiation indices $\left(\mathrm{G}_{\mathrm{sT}}\right.$ and $D$ ) (Table 4) confirmed the results of the genetic structure analyses; moderate differentiation among localities was observed within each genetic group. Differentiation was higher in $M$. pugana $\left(\mathrm{G}_{\mathrm{ST}}=0.120 \pm 0.021, D=0.028 \pm 0.007\right)$ than in M. pacifica s.s. $M$. vallartensis $\left(\mathrm{G}_{\mathrm{ST}}=0.106 \pm 0.016\right.$, $D=0.026 \pm 0.006$ ). Pairwise matrix analyses among localities using the Exact Test for population differentiation showed significant genetic differences $(p<0.05)$ among the localities that constitute the two subgroups of $M$. pugana (Table 5). This same result was observed when localities of $M$. pugana were compared to all of $M$. pacifica s.s.M. vallartensis studied localities. In contrast, pairwise matrix analysis within each $M$. pugana subgroup, and within the M. pacifica s.s. $-M$. vallartensis group showed no significant genetic differences. Mantel tests revealed a significant correlation between geographical and genetic distances across the M. pacifica species complex $r=0.80$, $p<0.001$, showing a significant effect of isolation by distance (IBD) (Figure 6). However, when Mantel tests were applied to each of the two genetic groups separately, no significant correlation between geographical and genetic distances was detected.

Conservation status assessment. The estimated EOO for M. pugana, M. pacifica, and M. vallartensis were 2178 , 3196 and $124 \mathrm{~km}^{2}$, respectively, and AOO were 100, 104, and $44 \mathrm{~km}^{2}$, respectively.

\section{Discussion}

Species delimitation and assessment of species diversity have broad implications to biological conservation and evolutionary analysis (Coates et al. 2018). The population genetics approach with ISSR markers used in this work was 
a)
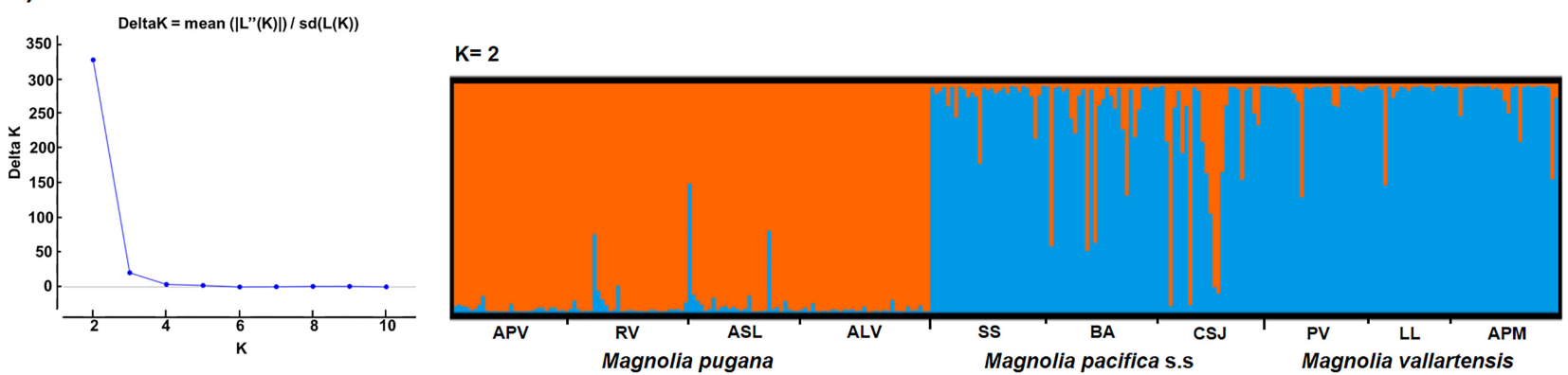

b)
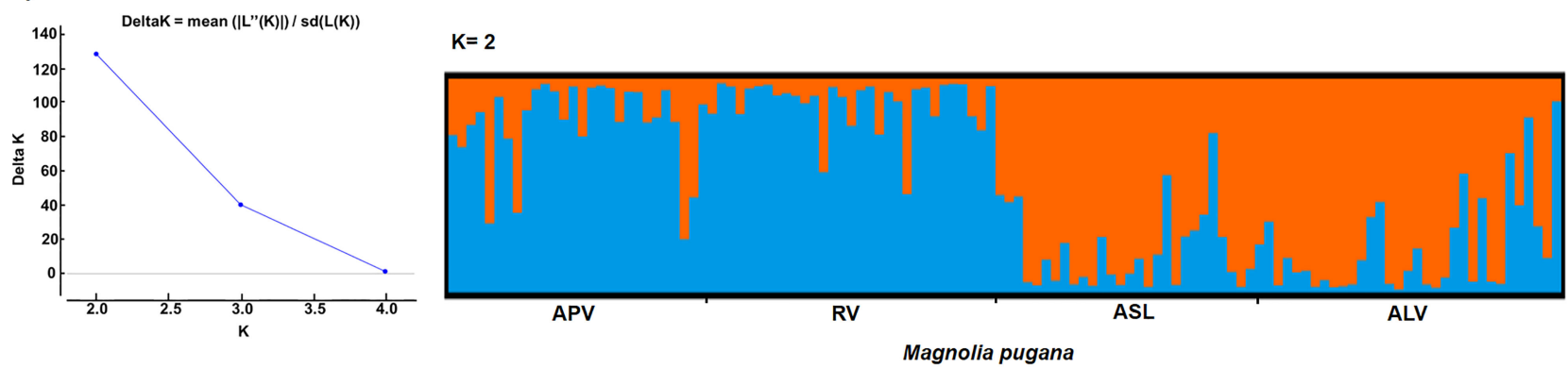

c)

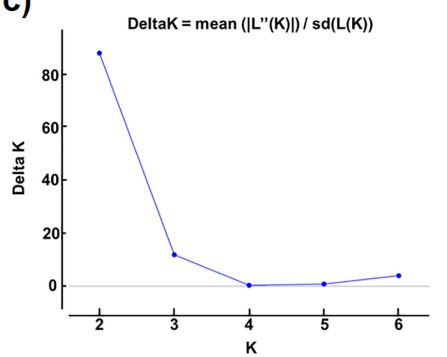

$\mathrm{K}=\mathbf{2}$

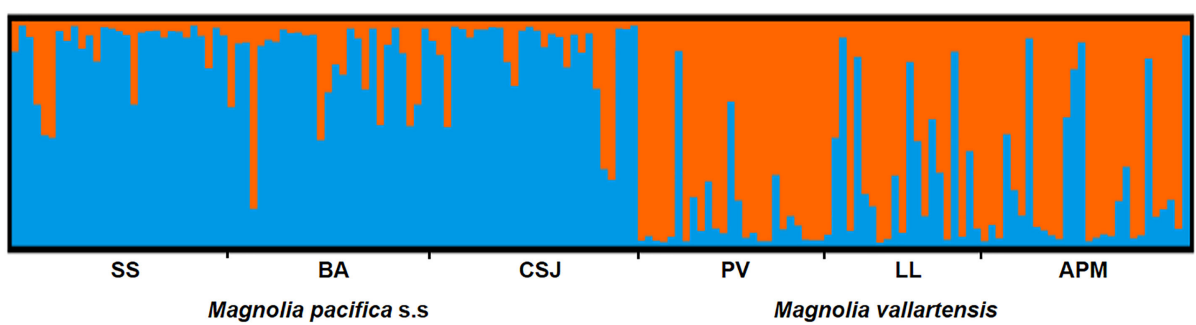

Figure 4. Results of Bayesian clustering based on the software STRUCTURE; analysis performed on a) the entire data set (278 individuals, 76 loci ISSR); b) the M. pugana group (120 individuals); c) the $M$. pacifica s.s.-M. vallartensis group (158 individuals). Relationships between $K$ and Delta $K$ values and structure bar plots are shown. Vertical bars represent each individual analyzed in this study and bars are divided into several colors when there is evidence of admixture.

useful to delineate species boundaries and relationships within the M. pacifica species complex. The genetic groups identified through a hierarchical Bayesian clustering analysis partially supported the current taxonomic delimitation among the studied species. In a first structure analysis, $M$. pugana was recognized as a genetically distinct group, whereas M. pacifica s.s. and M. vallartensis were clustered together. Barrier analysis results revealed that the TMVB acts as geographical barrier to gene flow between these two groups. The M. pugana group was internally more homogeneous (assignment proportion $>97 \%$ ) than the $M$. pacifica s.s.-M. vallartensis group; reduction in effective gene flow facilitates genetic and morphological divergences between these groups (Rieseberg \& Willis 2007).

Interestingly, the second genetic cluster analyses showed substructures within each main groups; M. pugana was divided in the ASL-ALV and RV-APV subgroups, whilst in the second main cluster M. pacifica s.s. was separated from $M$. vallartensis. These results were confirmed by the dendrogram resulting from the UPGMA analysis. However, AMOVA results were not fully conclusive for the identification of species boundaries in the complex, and although a significant proportion of genetic variation either among taxa or genetic groups was shown, it was similar to the proportion of variation found within taxa or genetic groups. Most of the variation ( $\geq 82 \%$ ) was explained by differences within localities, which suggests high levels of cross-pollination for the studied taxa (Loveless \& Hamrick 1984, Hamrick \& Godt 1989). This result coincides with a recent molecular study indicating a predominance of outcrossing reproductive mode in some Neotropical 
magnolias (Veltjen et al. 2018). In agreement with our results, population genetic approaches with arbitrary dominant markers such as ISSR and AFLP have proved to be useful in the delimitation of diverse plant species. Bayesian analysis of genetic population structure using STRUCTURE and dominant markers has been conducted by several authors. In particular, Medrano et al. (2014) recognized two main genetic lineages in an endemic group of Narcissus species; Rodrigues et al. (2015) identified three main evolutionary lineages in Cattleya species; Esfandani-Bozchaloyi et al. (2018) delimitated 10 Geranium species; Sheidai et al. (2018) applied this strategy in Crocus species delimitation; and Pinangé et al. (2019) identified two population lineages in closely Dyckia species. Similar to our findings, AMOVA results on some of the studies enlisted above were less informative than Bayesian model-based clustering.

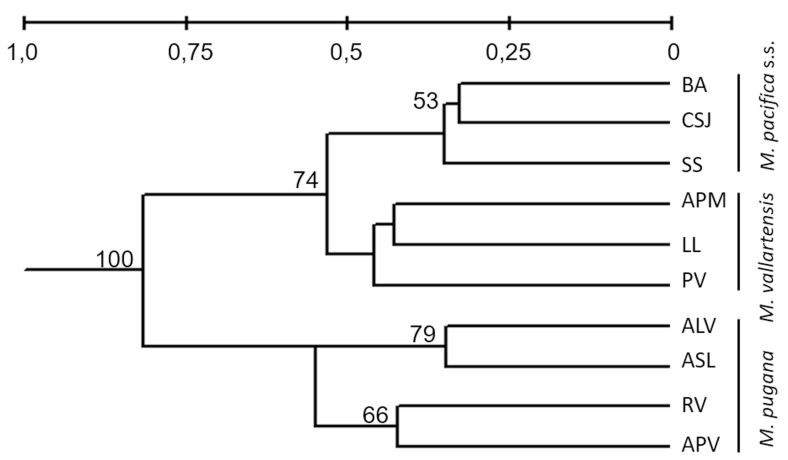

Figure 5. UPGMA dendrogram showing the genetic relationships of the M. pacifica species complex, the number at each node indicates the bootstrap percent having above $50 \%$ values.

The present study revealed that genetic differentiation among allopatric populations is occurring in M. pugana. Gene barrier analysis suggests that the Santiago river canyon (184 km long, 3-15 km wide and 0.5-0.7 km deep) may act as a barrier to gene flow by limiting pollination and seed dispersal between the two subpopulations of $M$. pugana. Localities ASL (type locality) and ALV found southwest of the canyon (Barranca del Río Santiago) form a subpopulation, hereafter referred to as M. pugana, while the RV and APV found northeast of the canyon, represent another subpopulation, hereafter referred to as the Barrancae group. The Santiago river canyon has also been reported as an important barrier that limits the gene flow between Nolina parviflora populations (Ruiz-Sanchez \& Specht 2013). According to Vázquez-García et al. (2016), allopatric speciation seems to be a major driver of Magnolia diversification in Neotropical Magnoliaceae. On the other hand, genetic differentiation between $M$. pacifica s.s. and $M$. vallartensis is also occurring, but this is lower than expected according to the morphological and ecological differentiation reported by Vázquez-García et al. (2012) and Dahua-Machoa (2018). Gene flow between these subgroups (assignment proportion $74 \%$ ) is higher than between the M. pugana subgroups (assignment proportion $70 \%$ ). The barrier detected between $M$. pacifica s.s. and M. vallartensis may correspond to several river canyons that stand among the sampled localities. Particularly CSJ is separated from the $M$. vallartensis localities by canyons of the rivers Ameca, Mascota, Cuale, and Pitillal; and SS is separated from $M$. vallartensis by the last three canyons. The climate in the lower zones of these canyons is too warm for these species. In contrast, there is no clear geographical or geomorphological barrier between some localities of these two taxa in the upper zones (i.e., BA and all the $M$. vallartensis localities). Therefore, genetic differences between these localities might be rather explained by a process of parapatric ecological differentiation (Nosil 2012). Sister species divergence in response to ecological factors is more frequent than formerly thought (Chapman et al. 2013, Anacker \& Strauss 2014). M. vallartensis and $M$. pacifica s.s. occupy different habitats (ecotone of tropical montane cloud forest and tropical sub-evergreen forest at 100-1,120 m elevation $v s$. montane cloud forest at 750-2,250 $\mathrm{m}$ elevation), they also differ in flowering seasonality (absent $v s$. high), seasonality of seed dehiscence (high vs. moderate), and production of flowers, fruits and seeds (low vs. regular) (Dahua-Machoa 2018). Furthermore,

Table 3. Molecular variance analysis (AMOVA) for Bayesian analysis and taxonomical groups of the Magnolia pacifica species complex.

\begin{tabular}{|c|c|c|c|c|c|}
\hline \multirow[b]{3}{*}{ Variation source } & \multicolumn{5}{|c|}{ Percentage of variation } \\
\hline & \multicolumn{2}{|c|}{ Groups } & \multicolumn{3}{|c|}{ Taxa } \\
\hline & Bayesian analysis (2) & Taxonomic (3) & M. pugana & M. pacifica s.s. & M. vallartensis \\
\hline \multicolumn{6}{|l|}{ Among } \\
\hline Taxa / Genetic groups & $9(0.001)$ & $8(0.001)$ & & & \\
\hline Localities & $9(0.001)$ & $8(0.001)$ & $12(0.001)$ & $7(0.001)$ & $7(0.001)$ \\
\hline \multicolumn{6}{|l|}{ Within } \\
\hline Localities & $82(0.001)$ & $84(0.001)$ & $88(0.001)$ & $93(0.001)$ & $93(0.001)$ \\
\hline
\end{tabular}

(2) two Bayesian groups, (3) three taxa, $p$ value is given in parentheses. 
[

Muñiz-Castro et al. / Botanical Sciences 98(3): 500-516. 2020

Table 4. Genetic diversity and differentiation parameters in all genetic groups, taxa and localities of the Magnolia pacifica complex.

\begin{tabular}{|c|c|c|c|c|c|c|c|c|c|}
\hline Genetic groups & Taxa & Locality & $\mathrm{P}(\%)$ & I & $\mathbf{H}_{\mathrm{E}}$ & $\mathbf{H}_{\mathrm{T}}$ & $\mathbf{H}_{\mathrm{s}}$ & $\mathbf{G}_{\mathrm{sT}}$ & D \\
\hline & & APV & 38 & 0.227 & 0.136 & & & & \\
\hline & & RV & 38 & 0.218 & 0.121 & & & & \\
\hline & & ASL & 39 & 0.230 & 0.140 & & & & \\
\hline & & ALV & 38 & 0.208 & 0.138 & & & & \\
\hline \multirow[t]{9}{*}{ M. pugana } & M. pugana & & 51 & 0.268 & & $0.158(0.023)$ & $0.134(0.020)$ & $0.120(0.021)$ & $0.028(0.007)$ \\
\hline & & SS & 38 & 0.209 & 0.140 & & & & \\
\hline & & BA & 47 & 0.280 & 0.178 & & & & \\
\hline & & CSJ & 41 & 0.233 & 0.159 & & & & \\
\hline & M. pacifica s.s. & & 51 & 0.272 & & $0.175(0.025)$ & $0.159(0.023)$ & $0.060(0.016)$ & $0.018(0.005)$ \\
\hline & & PV & 39 & 0.244 & 0.159 & & & & \\
\hline & & LL & 39 & 0.241 & 0.147 & & & & \\
\hline & & APM & 39 & 0.236 & 0.152 & & & & \\
\hline & M. vallartensis & & 46 & 0.275 & & $0.171(0.024)$ & $0.153(0.022)$ & $0.073(0.016)$ & $0.021(0.006)$ \\
\hline M. pacifica s.s - M. vallartensis & & & 53 & 0.289 & & $0.174(0.024)$ & $0.156(0.022)$ & $0.106(0.016)$ & $0.026(0.006)$ \\
\hline Total & & & 64 & 0.309 & & $0.178(0.023)$ & $0.147(0.020)$ & $0.222(0.039)$ & $0.040(0.009)$ \\
\hline
\end{tabular}

P proportion of polymorphic loci, I Shannon index, $\mathrm{H}_{\mathrm{E}}$ expected heterozygosity, $\mathrm{H}_{\mathrm{T}}$ total heterozygosity, $\mathrm{H}_{\mathrm{S}}$ intrapopulation heterozygosity, $\mathrm{G}_{\mathrm{ST}}$ fixation index, D Jost's differentiation index, standard deviation in parentheses.

M. vallartensis grows closer to the Pacific Ocean (0.5-20 vs. 40-70 km), with higher relative humidity and warmer climate (tropical maritime vs. temperate montane), higher mean annual temperature $\left(20.9-25.6{ }^{\circ} \mathrm{C}\right.$ vs. $\left.16.6-19.9^{\circ} \mathrm{C}\right)$ and higher annual rainfall $(1,348-1,591$ vs. $1,100-$ $1,364 \mathrm{~mm}$ ) (Fick \& Hijmans 2017).

Molecular analysis of closely related taxa that are still exchanging genes is a recent approach in speciation research (Gao et al. 2019, Chapman et al. 2013, Feder et al. 2012). Gene exchange among closely related taxa happens in at least $25 \%$ of plant species (Mallet 2005), therefore, further studies are necessary to assess the importance of parapatric and sympatric speciation in the Neotropical Magnolia species group. Complementary phylogenetic, biogeographic and phylogeographic studies are required to confirm species boundaries and relationships among the M. pacifica species complex revealed by ISSR dominant markers.

ISSR markers were found to be very effective in revealing the genetic variation within the $M$. pacifica complex. The genetic diversity estimates for the studied taxa $\left(\mathrm{H}_{\mathrm{T}}=0.158-0.175, \mathrm{I}=0.268-0.275\right)$, were lower than the average values usually reported for plant genetic diversity based on ISSR $(\mathrm{H}=0.22)$ (Nybom 2004), and much lower than those reported for two threatened eastern Mexican Magnolia species: M. sharpii Miranda $(\mathrm{I}=0.56)$ and M. schiedeana Schlecht. $(\mathrm{I}=0.50)$ (Newton et al.
2008). This is despite the fact that $M$. sharpii has an EOO $\left(2,228 \mathrm{~km}^{2}\right)$ similar to that of M. pugana $\left(2,178 \mathrm{~km}^{2}\right)$ and larger than that of $M$. vallartensis $\left(124 \mathrm{~km}^{2}\right)$. The three western Magnolia species of this study have much smaller EOO than that of the eastern M. schiedeana $\left(17,411 \mathrm{~km}^{2}\right)$ (Rivers et al. 2016); this difference in range size is in accordance with their lower genetic diversity. Genetic diversity of the taxa studied here is similar to that estimated for the rare and endangered Chinese species Magnolia cathcartii $\left(\mathrm{H}_{\mathrm{T}}=0.162, \mathrm{I}=0.27\right)$ using AFLP data (Zhang et al. 2010). Some other studies based on ISSR have also shown low levels of genetic diversity on endangered and endemic plant species (Luan et al. 2006, Li \& Jin 2007). M. pugana displayed the lowest genetic diversity $\left(\mathrm{H}_{\mathrm{T}}=\right.$ $0.157, \mathrm{H}_{\mathrm{s}}=0.134$ ) within the M. pacifica complex, this result is in accordance with expectations from population genetics theory for taxa with small populations in small geographic ranges (Godt \& Hamrick 1999, Cole 2003). The highly fragmented small subpopulations of M. pugana are the result of both natural and anthropogenic causes; because of its higher continentality, M. pugana is exposed to greater water stress (less rain and fog), and more forest fires than M. pacifica s.s. and M. vallartensis. M. pugana is not a cloud forest species, but an element of riparian gallery forest, usually surrounded by a matrix of drier habitats such as Quercus-Pinus and tropical seasonal dry forests, and anthropogenic pasturelands. 
Table 5. Nei's unbiased genetic distance (above diagonal) and Exact Test differentiation probability values (below diagonal) among sampled localities of the M. pacifica species complex.

\begin{tabular}{lcccccccccc}
\hline & \multicolumn{3}{c}{ M. pugana } & \multicolumn{5}{c}{ M. pacifica s.s. } & \multicolumn{3}{c}{ M. vallartensis } \\
\hline & APV & RV & ASL & ALV & SS & BA & CSJ & PV & LL & APM \\
\hline APV & - & 0.039 & 0.051 & 0.050 & 0.069 & 0.057 & 0.060 & 0.098 & 0.097 & 0.088 \\
RV & 0.079 & - & 0.054 & 0.052 & 0.074 & 0.070 & 0.073 & 0.110 & 0.112 & 0.088 \\
ASL & 0.006 & 0.001 & - & 0.032 & 0.060 & 0.065 & 0.050 & 0.077 & 0.079 & 0.072 \\
ALV & 0.013 & 0 & 0.144 & - & 0.070 & 0.069 & 0.066 & 0.099 & 0.097 & 0.080 \\
SS & 0 & 0 & 0.002 & 0 & - & 0.031 & 0.030 & 0.058 & 0.042 & 0.049 \\
BA & 0.002 & 0 & 0 & 0 & 0.520 & - & 0.032 & 0.065 & 0.042 & 0.045 \\
CSJ & 0 & 0 & 0 & 0 & 0.312 & 0.703 & - & 0.056 & 0.042 & 0.040 \\
PV & 0 & 0 & 0 & 0 & 0.060 & 0.052 & 0.050 & - & 0.039 & 0.043 \\
LL & 0 & 0 & 0 & 0 & 0.060 & 0.475 & 0.119 & 0.976 & - & 0.038 \\
APM & 0 & 0 & 0 & 0 & 0.360 & 0.210 & 0.162 & 0.550 & 0.360 & - \\
\hline
\end{tabular}

Overall, differentiation indices $\left(\mathrm{G}_{\mathrm{ST}}\right.$ and $\left.\mathrm{D}\right)$ were moderate and revealed that gene flow is ongoing within each genetic group or taxon. They were lower $\left(\mathrm{G}_{\mathrm{ST}}=0.060\right.$ $0.120)$ than those reported for the critically endangered M. coriacea $\left(\mathrm{G}_{\mathrm{ST}}=0.187\right)$ estimated from ISSR markers (Zhao et al. 2012). Similarly, genetic patterns in various Neotropical Magnolia species were recently investigated and population differentiation was considered moderate to high in most species (Veltjen et al. 2018). The Exact Text of population differentiation confirmed the genetic structure and relationships observed in the $M$. pacifica complex. Genetic differentiation in Magnolia might be favored by limitations of pollination mechanisms, seed dispersal and initial establishment of seedlings (Loveless \& Hamrick 1984). It is known that the transfer of pollen by beetles in small and isolated populations of Magnolia is not very efficient (Huang \& Guo 2002, Chen et al. 2016), and flowering times do not always correspond with the emergence of pollinators (Dieringer \& Espinosa 1994). Habitat fragmentation and other anthropogenic factors may also be troublesome for Magnolia seed dispersal by birds (Oppel \& Mack 2010, Chen et al. 2016); even if dispersal occurs, seeds may not germinate or seedlings may not survive in places without enough humidity all year round (José et al. 2011). The limited gene flow between M. pugana and the Barrancae group or M. pacifica s.s. and M. vallartensis can exacerbate genetic differentiation and loss of genetic variation. Finally, results from the Mantel test applied to all localities of the complex and to each main genetic cluster suggest that geographic distance may have contributed to differentiation between population lineages but not within them.

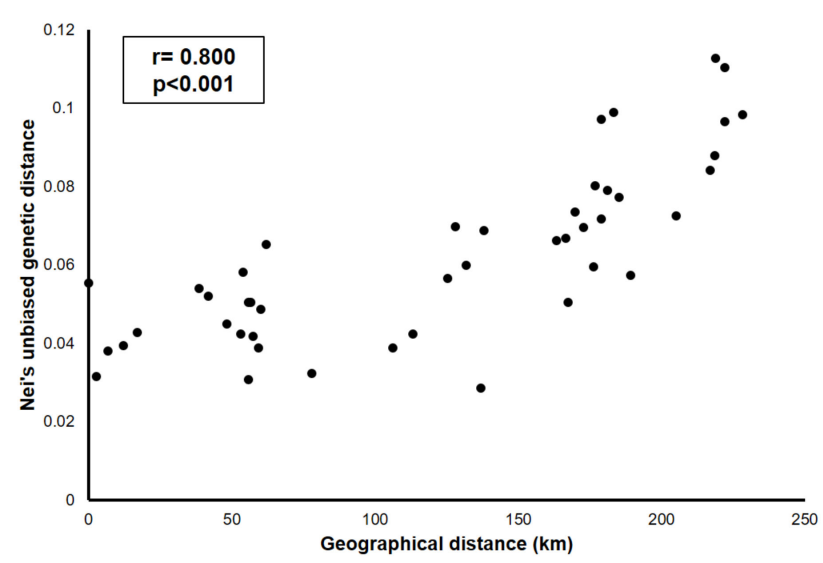

Figure 6. Correlation between genetic and geographic distances, $r=$ correlation index, $p=$ significance value.

Results from this study provide relevant and significant information for conservation strategies of M. pugana, M. pacifica s.s. and M. vallartensis. These western Mexican species are in an endangered status because of their highly fragmented populations, surrounded by seasonal drier habitats (Fick \& Hijmans 2017), lower genetic diversity and narrower extent of occurrence compared with other threatened Magnolia species (Newton et al. 2008). EOO and $\mathrm{AOO}$ estimates for all three taxa are in accordance with the IUCN criteria for endangered species: B1 (EOO $\left.<5,000 \mathrm{~km}^{2}\right)$ and $\mathrm{B} 2\left(\mathrm{AOO}<500 \mathrm{~km}^{2}\right)$. In addition, populations of these taxa are severely fragmented and present a continuing decline in the area, quality of habitat, and number of mature individuals [IUCN criteria B1ab (iii,v) + B2ab (iii,v)] (IUCN 2019). Measures of genetic diversity are not explicitly considered in the IUCN Red List of threatened species, however, this criterion is taken into account in the MER of the Mexican Official Norm 059 (SEMARNAT 2010). The genetic diversity of the three taxa studied here is considered lower than the average $(\mathrm{H}=0.22)$ for diverse plant species with dominant markers (Nybom 2004), and it is even lower than that of M. sharpii $(\mathrm{I}=0.56)$, a species categorized as endangered because of its narrow EOO $\left(2,228 \mathrm{~km}^{2}\right)$, severely fragmented and degraded habitats, and the fact that it is known from only five locations (Newton et al. 2008, Rivers et al. 2016). The low genetic diversity of the three taxa of the $M$. pacifica complex is in accordance with criterion C-2 (intrinsic biological vulnerability: genetic variability factor) of the MER for endangered species (SEMARNAT 2010).

In order to maintain the genetic diversity within the M. pacifica species complex as high as possible (Avise \& Hamrick 1996, Xiao et al. 2004), the two subpopulations of M. pugana, and the subpopulations of M. pacifica s.s. and $M$. vallartensis should be considered as separate units of conservation. The implementation of in situ and ex situ conservation programs should protect and preserve at least 
one locality of each subpopulation of $M$. pugana and the most divergent localities of $M$. pacifica s.s. (BA and the type locality $\mathrm{SS}$ ) and $M$. vallartensis ( $\mathrm{PV}$ and the type locality APM). The BA locality of M. pacifica s.s. presented the highest genetic variability, which coincides with being the most important forest (maple forest) in terms of woody species richness, vascular plant endemism and floristic composition for western Mexico (Vázquez-García et al. 2000, Vargas-Rodríguez et al. 2010). Concerted efforts must be made to conserve all of these taxa, and a greater focus is required to protect M. pugana characterized by low levels of genetic variation. Moreover, $M$. pacifica s.s. and M. vallartensis must also be protected, because of their current threatened status according to the IUCN criteria (IUCN Standards and Petitions Committee 2019). These three taxa must be fully assessed with the MER method for inclusion in the list of endangered species in the official Mexican Norm NOM-059. Ecological studies in relation to future climatic scenarios should also be carried out in order to assess their impact on endangered species of Magnolia in western Mexico. Management plans and education in conservation issues, linked to workshops to rural and indigenous communities are badly needed to train people in propagation techniques of magnolias in order to decrease their threatened status and raise awareness of the fate of these relict species in extinction risk.

\section{Acknowledgments}

This work was supported by Secretaría de Educación Pública (SEP-México) through its PRODEP program PROMEP-NPTC/103.5/12/3418 for the first author, by Universidad de Guadalajara, Mexico, through its PRO-SNI program for the first and fourth authors, a scholarship to the third author, and the P3E 2013-2016 project of CUCBA. We are grateful to Vallarta Botanical Gardens, Bob Price, Neil Gerlowski, Ralph Osborne, Magnolia Society International and Botanical Gardens Conservation International for financial and logistical support. We thank Ana T. Nuño Rubio, Abel Puente Casillas, Jesús Padilla Lepe, César Jacobo Pereira, Rosa Murguía Araiza and Ricardo Díaz Borioli for field assistance.

\section{Supplemental data}

Supplemental material for this article can be accessed here: https://doi.org/10.17129/botsci.2551

\section{Literature Cited}

Anacker BL, Strauss SY. 2014. The geography and ecology of plant speciation: range overlap and niche divergence in sister species. Proceedings of the Royal Society 281: 2013-2980. DOI: https://doi.org/10.1098/rspb.2013.2980

APG IV. 2016. An update of the Angiosperm Phylogeny Group classification for the orders and families of flowering plants: APG IV. Botanical Journal of the
Linnean Society 181: 1-20. DOI: https://doi.org/10.1111/ boj. 12385

Avise JC, Hamrick JL. 1996. Conservation Genetics: Case Histories from Nature. New York, USA: Chapman and Hall. ISBN: 041-2055813

Chapman MA, Hiscock SJ, Filatov DA. 2013. Genomic divergence during speciation driven by adaptation to altitude. Molecular Biology and Evolution 30: 2553-2567. DOI: https://doi.org/10.1093/molbev/mst168

Chen Y, Chen G, Yang J, Sun W. 2016. Reproductive biology of Magnolia sinica (Magnoliaecea), a threatened species with extremely small populations in Yunnan, China. Plant Diversity 38: 253-258. DOI: https://doi.org/ 10.1016/j.pld.2016.09.003

Cicuzza D, Newton A, Oldfield S. 2007. The Red List of Magnoliaceae. Cambridge, UK: Fauna \& Flora International. ISBN: 9781-903703-23-6

Cires E, De Smet Y, Cuesta C, Goetghebeur P, Sharrock S, Gibbs D, Oldfield S, Kramer A, Samain MS. 2013. Gap analyses to support ex situ conservation of genetic diversity in Magnolia, a flagship group. Biodiversity and Conservation 22: 267-290. DOI: https://doi.org/10.1007/ s10531-013-0450-3

Coates DJ, Byrne M, Moritz C. 2018. Genetic diversity and conservation units: dealing with the species-population continuum in the age of genomics. Frontiers in Ecology and Evolution: 6: 1-13. DOI: https://doi.org/10.3389/ fevo.2018.00165

Cole CT. 2003. Genetic variation in rare and common plants. Annual Review of Ecology, Evolution, and Systematics 34: 213-37. DOI: https://doi.org/10.1146/ annurev.ecolsys.34.030102.151717

Cota-Sánchez JH, Remrchuk K, Ubayasena K. 2006. Ready to use DNA extracted with CTAB method adapted for herbarium specimens and mucilaginous plant tissue. Plant Molecular Biology Reporter 24: 161-167. DOI: https://doi.org/10.1007/BF02914055

Dahua-Machoa A. 2018. Temporalidad de fenofases $y$ micropropagación in vitro de tres especies relictuales de Magnolia del Occidente de México: implicaciones para su conservación in situ y ex situ. MSc. Thesis, Universidad de Guadalajara, México.

de Queiroz K. 2005. Ernst Mayr and the modern concept of species. Proceedings of the National Academy of Sciences 102: 6600-6607. DOI: https://doi.org/10.1073/ pnas. 0502030102

de Queiroz K. 2007. Species Concepts and Species Delimitation. Systematic Biology 56: 879-886. DOI: https://doi.org/10.1080/10635150701701083

Dieringer G, Espinosa JE. 1994. Reproductive ecology of Magnolia schiedeana (Magnoliaceae), a threatened cloud forest tree species in Veracruz, Mexico. Bulletin of the Torrey Botanical Club 121: 154-159. DOI: https:// doi.org/10.2307/2997167 
Drummond C, Hamilton M. 2007. Hierarchical components of genetic variation at a species boundary: population structure in two sympatric varieties of Lupinus microcarpus (Leguminosae). Molecular Ecology 16: 753-769. DOI: https://doi.org/10.1111/j.1365-294X.20 06.03186.x

Duminil J, \& Di Michele M. 2009. Plant species delimitation: A comparison of morphological and molecular markers. Plant Biosystems 143: 528-542. DOI: https://doi.org/10.1080/11263500902722964

Esfandani-Bozchaloyi S, Sheidai M, Keshavarzi M, Noormohammadi Z. 2018. Species relationship and population structure analysis in Geranium subg. Robertium with the use of ISSR molecular markers. Acta Botanica Hungarica 60: 47-65. DOI: http://doi.org/ $\underline{10.1556 / 034.60 .2018 .1-2.4}$

Evanno G, Regnaut S, Goudet J. 2005. Detecting the number of clusters of individuals using the software STRUCTURE: a simulation study. Molecular Ecology 14: 2611-2620. DOI: https://doi.org/10.1111/j.1365-294 X.2005.02553.x

Feder JL, Egan SP, Nosil P. 2012. The genomics of speciation-with-gene flow. Trends in Genetics 28: 342-350. DOI: https://doi.org/10.1016/j.tig.2012.03.009

Fernandes-Lima D, Mauad AVS, Silva-Pereira V, CamargoSmidt E, Goldenberg R. 2015. Species boundaries inferred from ISSR markers in the Myrcia laruotteana complex (Myrtaceae). Plant Systematics and Evolution 301: 353-363. DOI: https://doi.org/10.1007/s00606-014$\underline{1078-9}$

Fick SE, Hijmans RJ. 2017. Worldclim 2: New 1-km spatial resolution climate surfaces for global land areas. International Journal of Climatology 37: 4302-4315. DOI: https://doi.org/10.1002/joc.5086

Figlar RB. 2006. Taxonomy topics - A new classification for Magnolia. In: Evans P, ed. Rhododendrons with Camellias and Magnolias Yearbook 2006. Woking, UK: Royal Horticultural Society. pp. 69-82. ISBN 13: 9781902896595

Figlar RB, Nooteboom HP. 2004. Notes on Magnoliaceae IV. Blumea 49: 87-100. DOI: https://doi.org/10.3767/ $\underline{000651904 X 486214}$

Frodin D, Govaerts R. 1996. World checklist and bibliography of MagnoliaceaeMichigan, USA: Royal Botanic Gardens, Kew. ISBN: 978-190-0347-07-5

Gao YD, Gao XF, Harris A. 2019. Species Boundaries and Parapatric Speciation in the Complex of Alpine Shrubs, Rosa sericea (Rosaceae), Based on Population Genetics and Ecological Tolerances. Frontiers in Plant Science 10: 1-16 DOI: https://doi.org/10.3389/fpls.2019.00321

Godt MJW, Hamrick JL. 1999. Genetic divergence among infraspecific taxa of Sarracenia purpurea. Systematic Botany 23: 4027-38. DOI: https://doi.org/10.2307/241 $\underline{9375}$
Gratani L. 2014. Plant phenotypic plasticity in response to environmental factors. Advances in Botany 208747: 1-17. DOI: https://doi.org/10.1155/2014/208747

Hamrick JL, Godt MJW. 1989. Allozyme diversity in plant species. In Brown AHD, Clegg MT, Kahler AL, Weir BS, eds. Plant Population Genetics, Breeding, and Genetic Resources. Sunderland, USA: Sinauer Associates Inc. pp. 43-63. ISBN: 0-87893-117-1

Hausdorf B, Hennig C. 2010. Species delimitation using dominant and codominant multilocus markers. Systematic Biology 59: 491-503. DOI: https://doi.org/ $10.1093 /$ sysbio/syq039

Hey J, Pinho C. 2012. Population genetics and objectivity in species diagnosis. Evolution 66: 1413-1429. DOI: http://doi.org/10.1111/j.1558-5646.2011.01542.x

Holderegger R, Kamm U, Gugerli F. 2006. Adaptive vs. neutral genetic diversity: Implications for landscape genetics. Landscape Ecology 21: 797-807. DOI: https:// doi.org/10.1007/s10980-005-5245-9

Huang SQ, Guo YH. 2002. Variation of pollination and resource limitation in a low seed-set tree, Liriodendron chinense (Magnoliaceae). Botanical Journal of the Linnean Society 140: 31-38. DOI: https://doi.org/10. 1046/j.1095-8339.2002.00080.x

INEGI [Instituto Nacional de Estadística, Geografía e Informática]. 2001. Conjunto de datos vectoriales Fisiográficos. Continuo Nacional serie I. Provincias fisiográficas. https://www.inegi.org.mx/app/biblioteca/fic $\underline{\text { ha.html} \text { ?upc }=702825267575}$ (accessed September 29, 2019).

IUCN [International Union for Conservation of Nature]. 2019. Red List of Threatened Species. Red List version 2019-3. https://www.iucnredlist.org (accessed November 11, 2019).

IUCN Standards and Petitions Committee [International Union for Conservation of Nature]. 2019. Guidelines for Using the IUCN Red List Categories and Criteria. Version 14. Prepared by the Standards and Petitions Committee. https://www.iucnredlist.org/resources/redlist guidelines (accessed October 20, 2019).

José AC, da Silva EAA, Davide AC, Melo AJS, Toorop PE. 2011. Effects of drying rate and storage time on Magnolia ovata Spreng. seed viability. Seed Science and Technology 39: 425-434. DOI: https://doi.org/10.15258/ sst.2011.39.2.14

Jost L. 2008. $\mathrm{G}_{\mathrm{ST}}$ and its relatives do not measure differentiation. Molecular Ecology 17: 4015-4026. DOI: https://doi.org/10.1111/j.1365-294X.2008.03887.x

Kew-IUCN-VIBRANT. 2019. GeoCAT: Geospatial Conservation Assessment Tool. Kew-IUCN-VIBRANT. http://geocat.kew.org (accessed November 30, 2019).

Kim S, Suh Y. 2013. Phylogeny of Magnoliaceae based on ten chloroplast DNA regions. Journal of Plant Biology 
56: 290-305. DOI: https://doi.org/10.1007/s12374-0130111-9

Kopelman NM, Mayzel J, Jakobsson M, Rosenberg NA, Mayrose I. 2015. CLUMPAK: a 744 program for identifying clustering modes and packaging population structure inferences across 745 K. Molecular Ecology Resources 15: 1179-1191. DOI: https://doi.org/10.1111/ 1755-0998.12387

Li JM, Jin ZX. 2007. Genetic variation and differentiation in Torreya jackii Chun, an endangered plant endemic to China. Plant Science 172: 1048-1053. DOI: https:// doi.org/10.1016/j.plantsci.2007.02.009

Loveless MD, Hamrick JL. 1984. Ecological determinants of genetic structure in plant populations. Annual Review of Ecology and Systematics 15: 65-95. DOI: https:// doi.org/10.1146/annurev.es.15.110184.000433

Lozano-Contreras G. 1994. Dugandiodendron y Talauma (Magnoliaceae) en el Neotrópico. Colección Jorge Álvarez Lleras No. 3. Bogotá, Colombia: Academia Colombiana de Ciencias Exactas, Físicas y Naturales. ISBN: 958-9205-00-3

Luan S, Chiang TY, Gong X. 2006. High genetic diversity vslow genetic differentiation in Nouelia insignis (Asteraceae), a narrowly distributed and endemic species in China, revealed by ISSR fingerprinting. Annals of Botany. 98: 583-589. DOI: https://doi.org/10.1093/aob/ $\underline{\operatorname{mcl} 129}$

Magallón S, Gomez-Acevedo S, Sanchez-Reyes LL, Hernandez-Hernandez T. 2015. A metacalibrated timetree documents the early rise of flowering plant phylogenetic diversity. New Phytologist 207: 437-453. DOI: https://doi.org/10.1111/nph.13264

Mallet J. 2005. Hybridization as an invasion of the genome. Trends in Ecology \& Evolution 20: 229-237. DOI: https://doi.org/10.1016/j.tree.2005.02.010

Manni F, Guerard E, Heyer E. 2004. Geographic patterns of (genetic, morphologic, linguistic) variation: how barriers can be detected by using Monmonier's algorithm. Human Biology 76: 173-190. DOI: https://doi.org/10.1353/hub. $\underline{2004.0034}$

Medrano M, Lopez-Perea E, Herrera CM. 2014. Population genetics methods applied to a species delimitation problem: Endemic trumpet daffodils (Narcissus section Pseudonarcissi) from the southern Iberian Peninsula. International. Journal of Plant Sciences 175: 501-517. DOI: $\underline{\text { https://doi.org/10.1086/675977 }}$

Meirmans PG, Van Tienderen PH. 2004. GENOTYPE and GENODIVE: two programs for the analysis of genetic diversity of asexual organisms. Molecular Ecology Resources 4: 792-794. DOI: https://doi.org/10.1111/ j.1471 - -8286.2004.00770.x
Miller MP. 1997. Tools for Population Genetic Analysis (TFPGA), Version 1.3. Arizona: Department of Biological Sciences, Northern Arizona University.

Monmonier MS. 1973. Maximum-difference barriers: an alternative numerical regionalization method. Geographical Analysis 5: 245-261. DOI: https://doi.org/ 10.1111/j.1538-4632.1973.tb01011.x

Nei M. 1972. Genetic distance between populations. The American Naturalist 106: 283-292.

Newton AC, Gow J, Robertson A, Williams-Linera G, Ramírez-Marcial N, González-Espinosa M, Allnutt TR, Ennos R. 2008. Genetic variation in two rare endemic Mexican trees, Magnolia sharpii and Magnolia schiedeana. Silvae Genetica 57: 348-356. DOI: https:// doi.org/10.1515/sg-2008-0051

Noble D, Qi Y, Fu J. 2010. Species delineation using Bayesian model-based assignment test: a case study using Chinese toad-headed agamas (genus Phrynocephalus). BMC Evolutionary Biology 10: 1-15. DOI: https://doi.org/10.1186/1471-2148-10-197

Nosil P. 2012. Ecological speciation. New York, USA: Oxford University Press Inc. ISBN: 9780199587117

Nybom H. 2004. Comparison of different nuclear DNA markers for estimating intraspecific genetic diversity in plants. Molecular Ecology 13: 1143-1155. DOI: https:// doi.org/10.1111/j.1365-294X.2004.02141.x

Oppel S, Mack AL. 2010. Bird assemblage and visitation pattern at fruiting Elmerrillia tsiampaca (Magnoliaceae) trees in Papua New Guinea. Biotropica 42: 229-235. DOI: https://doi.org/10.1111/j.1744-7429.2009.00572.x

Petit RJ, Excoffier L. 2009. Gene flow and species delimitation. Trends in Ecology \& Evolution 24: 386-393. DOI: https://doi.org/10.1016/j.tree.2009.02.011

Pinangé DSB, RB, Wöhrmann T, Krapp F, Weising K, Zizka G, Polo EM, Wanderley MGL, Benko-Iseppon AM. 2019. Population genetics shed light on species delimitation and life history of the Dyckia pernambucana complex (Bromeliaceae). Botanical Journal of the Linnean Society 192: 706-725. DOI: https://doi.org/10.1093/botlinnean/boz106

Pritchard JK, Stephens M, Donnelly P. 2000. Inference of population structure using multilocus genotype data. Genetics 155: 945-959. https://www.genetics.org/cont ent/155/2/945

Raymond M, Rousset F. 1995. An exact test for population differentiation. Evolution 49: 1280-1283. DOI: https:// doi.org/10.1111/j.1558-5646.1995.tb04456.x

Reddy MP, Sarla N, Siddiq EA. 2002. Inter simple sequence repeat (ISSR) polymorphism and its application in plant breeding. Euphytica 128: 9-17. DOI: https://doi.org/10.1023/A:1020691618797 
Rieseberg LH, Willis JH. 2007. Plant Speciation. Science 317: 91-914. DOI: https://doi.org/10.1126/science.113 7729

Rivers M, Beech E, Murphy L, Oldfield S. 2016. The Red List of Magnoliaceae (Revised and Extended). Richmond, UK: Botanic Gardens Conservation International. ISBN: 1-905164-64-5

Rodrigues JF, Van den Berg C, Abreu AG, Novello M, Veasey EA, Oliveira GCX, Koehler S. 2015. Species delimitation of Cattleya coccinea and C. mantiqueirae (Orchidaceae): insights from phylogenetic and population genetics analyses. Plant Systematics and Evolution 301: 1345-1359. DOI: https://doi.org/10.1007/ s00606-014-1156-z

Romanov MS, Dilcher DL. 2013. Fruit structure in Magnoliaceae S.L. and Archeaenthus and their relationships. American Journal of Botany 100: 1494-1508. DOI: https://doi.org/10.3732/ajb.1300035

Rosenberg N. 2003. The shapes of neutral gene genealogies in two species: probabilities of monophyly, paraphyly, and polyphyly in a coalescent model. International Journal of Organic Evolution 57: 1465-1477. DOI: https://doi.org/10.1111/j.0014-3820.2003.tb00355.x

Ruiz-Sánchez E, Specht CD. 2013. Influence of the geological history of the Trans-Mexican Volcanic Belt on the diversification of Nolina parviflora (Asparagaceae: Nolinoideae). Journal of Biogeography 40: 1336-1347. DOI: https://doi.org/10.1111/jbi.12073

Schemske DW, Husband BC, Ruckelshaus MH, Goodwillie C, Parker IM, Bishop JG. 1994. Evaluating approaches to the conservation of rare and endangered plants. Ecology 75: 584-606. DOI: https://doi.org/10.2307/1941 $\underline{718}$

Schlick-Steiner BC, Steiner FM, Seifert B, Stauffer C, Christian E, Crozier RH. 2010. Integrative taxonomy: a multisource approach to exploring biodiversity. Annual Review of Entomology 55: 421-438. DOI: https://doi.org/ $\underline{10.1146 / \text { annurev-ento-112408-085432 }}$

SEMARNAT [Secretaría del Medio Ambiente y Recursos Naturales]. 2010. Norma Oficial Mexicana NOM-059SEMARNAT-2010, Protección ambiental-Especies nativas de México de flora y fauna silvestres-Categorías de riesgo y especificaciones para su inclusión, exclusión o cambio-Lista de especies en riesgo. Diario Oficial de la Federación. Anexo Normativo II. Pp. 14-18. 2da. Sección, 30 de diciembre de 2010.

Sheidai M, Teymoori H, Noormohammadi Z, Mahrabian AR, Koohdar F, Ghassemzadeh-Baraki S. 2018. Species delimitation in the genus Tamarix: Morphological and molecular data. Phytotaxa 343: 101-115. DOI: https:// doi.org/10.11646/phytotaxa.343.2.1

Sites JW, Marshall JC. 2004. Operational criteria for delimiting species. Annual Review of Ecology, Evolution, and Systematics 35: 199-227. DOI: https://doi.org/ 10.1146/annurev.ecolsys.35.112202.130128

Snow R. 2005. Continental climate and continentality. In: Oliver JE ed. Encyclopedia of World Climatology, Encyclopedia of Earth Sciences Series. Dordrecht: Springer Netherlands, pp. 303-305. ISBN: 978-1-4020-4870-8

Sokal RR, Rohlf FJ. 1995. Biometry: The principles and practice of statistics in biological research. New York: WH. Freeman \& Co. ISBN: 0-7167-8604-4

Stiehl-Alves EM, Kaktchuk-Santos E, Eggers L, SouzaChies T. 2017. Using a population genetics approach for a preliminary investigation concerning Species boundaries in Herbetia (Iridaceae). International Journal of Plant Sciences 178: 439-449. DOI: https://doi.org/ $\underline{10.1086 / 692014}$

Vargas-Rodríguez YL, Platt WJ, Vázquez-García JA, Boquin G. 2010. Selecting relict montane cloud forests for conservation priorities: the case of western Mexico. Natural Areas Journal 30: 156-173. DOI: https://doi.org/ $\underline{10.3375 / 043.030 .0204}$

Vázquez-García JA. 1994. Magnolia (Magnoliaceae) in México and Central America: A Synopsis. Brittonia 46: 1-23. DOI: https://doi.org/10.2307/2807454

Vázquez-García JA, Carvajal S, Hernández L. 2002. Magnolia pugana (Magnoliaceae): Una nueva combinación en el complejo $M$. pacifica. Novon 12: 137-141. DOI: https://doi.org/10.2307/3393253

Vázquez-García JA, Muñiz-Castro MÁ, Arroyo F, Pérez ÁJ, Serna M, Cuevas-Guzmán R, De Castro-Arce E, Gurrola-Díaz CM. 2013. Novelties in Neotropical Magnolia and an addendum proposal to the IUCN Red List of Magnoliaceae. In: Salcedo-Pérez E, HernándezÁlvarez E, Vázquez-García JA, Escoto-García T, DíazEchavarría N, eds. Recursos Forestales del Occidente de México: Diversidad, Manejo, Aprovechamiento y Conservación, Serie Fronteras de Biodiversidad, Universidad de Guadalajara CUCEI-CUCBA, Guadalajara, Vol. 4 Tomo 2, pp. 61-496. ISBN: 978-607-8072-56-9

Vázquez-García JA, Muñiz-Castro MÁ, De Castro E, Murguía R, Nuño A, Cházaro M. 2012. Twenty new tropical tree species of Magnolia (Magnoliaceae). In: Salcedo-Pérez E, Hernández-Álvarez E, Vázquez-García JA, Escoto-García T, Díaz-Echevarría N, eds. Recursos Forestales del Occidente de México: Producción, Manejo, Aprovechamiento y Conservación. Universidad de Guadalajara CUCBA. Guadalajara, Jalisco, México, pp. 91-130. ISBN: 978-607-8072-56-9

Vázquez-García JA, Neill DA, Asanza M, Pérez ÁJ, Arroyo F, Dahua-Machoa A, Merino-Santi RE. 2016. Magnolias de Ecuador: en riesgo de extinción. Universidad Estatal Amazónica, Universidad de Guadalajara-CUCBA, 
Pontificia Universidad Católica de Ecuador, Universidad Nacional Agraria La Molina, Puyo, ECUADOR. ISBN: 978-9942-932-18-1

Vázquez-García JA, Pérez-Farrera MÁ, Gómez-Domínguez H, Muñiz-Castro MÁ, Sahagún-Godínez E. 2017. Magnolia montebelloensis, a new species in section Magnolia from Lagunas de Montebello National Park, Chiapas, México, with a key to Magnoliaceae of Chiapas. Phytotaxa 328: 101-114. DOI: https://doi.org/ 10.11646/phytotaxa.328.2.1

Vázquez-García JA, Vargas-Rodríguez YL, Aragón F. 2000. Descubrimiento de un bosque de AcerPodocarpus-Abies en el Municipio de Talpa de Allende, Jalisco, México. Ibugana 7: 159-183.

Veltjen E, Asselman P, Hernández M, Palmarola A, Testé E, González LR, Goetghebeur P, Larridon I, Samain MS. 2018. Genetic patterns in Neotropical magnolias (Magnoliaceae) using de novo developed microsatellite markers. Heredity 122: 485-500. DOI: https://doi.org/ 10.1038/s41437-018-0151-5

Wang W, Li H, Chen Z. 2014. Analysis of plastid and nuclear DNA data in plant phylogenetics evolution and improvement. Science China, Life Sciencies 57: 280-286. DOI: https://doi.org/10.1007/s11427-014-4620-7

Xiao LQ, Ge XJ, Gong X, Hao G, Zheng SX. 2004. ISSR Variation in the endemic and endangered plant Cycas guizhouensis (Cycadaceae). Annals of Botany Oxford 94 : 133-138. DOI: https://doi.org/10.1093/aob/mch119
Yeh F, Yang R, Boyle T. 1999. POPGENE Version 1.32. Microsoft Window-based freeware for Population Genetic Analysis. Canada: Molecular Biology and Biotechnology Center, University of Alberta.

Zhang XM, Wen J, Dao ZL, Motley TJ, Long CL. 2010. Genetic variation and conservation assessment of Chinese populations of Magnolia cathcartii (Magnoliaceae), a rare evergreen tree from the SouthCentral China hotspot in the Eastern Himalayas. Journal of Plant Research 123: 321-331. DOI: https://doi.org/ 10.1007/s10265-009-0278-9

Zhao X, Ma Y, Sun W, Wen X, Milne R. 2012. High Genetic diversity and low differentiation of Michelia coriacea (Magnoliaceae), a critically endangered endemic in Southeast Yunnan, China. International Journal of Molecular Sciences 13: 4396-4411. DOI: https://doi.org/10.3390/ijms13044396

Zhou Y, Duvaux L, Ren G, Zhang L, Savolainen O, Liu J. 2017. Importance of incomplete lineage sorting and introgression in the origin of shared genetic variation between two closely related pines with overlapping distributions. Heredity 118: 211-220. DOI: https:// doi.org/10.1038/hdy.2016.72

Zietkiewicz E, Rafalski, Labuda AD. 1994. Genome fingerprinting by simple sequence repeat (SSR)anchored polymerase chain reaction amplification. Genomics 20: 176-183. DOI: https://doi.org/10.1006/ geno.1994.1151

\footnotetext{
Associated Editor: Alejandro Casas

Author contributions: All authors contributed to securing funding, writing and reviewing the manuscript. MAMC, idea conception, study design, fieldwork, data analysis; LPCF, idea conception, study design, laboratory work, data analysis; ASCA, field and laboratory work, data analysis; JAVG, idea conception, study design, provided morphological, ecological, and distribution data; AS, laboratory work, data analysis.
} 